\title{
Geo-electric method applied to groundwater protection of a granular sandstone aquifer
}

\author{
Nuhu Degree Umar ${ }^{1} \cdot$ Ogbonnaya Igwe $^{1}$
}

Received: 6 July 2018 / Accepted: 15 May 2019 / Published online: 25 May 2019

(C) The Author(s) 2019

\begin{abstract}
The geo-electric properties of the granular sandstone aquifer of Lafia and environs were evaluated for the purpose of groundwater management. Vertical electrical sounding (VES) using Schlumberger electrode array with a maximum half current electrode separation of $400 \mathrm{~m}$ was employed. Interpretation of the VES results showed that the area is characterized by 4-5 geo-electric subsurface layers, viz. topsoil/laterite, sandy clay, clayey sand, sandstone and shale while the APC varies from very good $4 \%$, good $36 \%$, moderate $30 \%$ and weak-poor $30 \%$. Approximately, $82.22 \%$ of the study area is practically noncorrosive, while parts of the southern, south-western and central parts fall under slightly corrosive (13.33\%) to moderately corrosive $(4.5 \%)$. Groundwater quality varied from excellent (13.33\%), good (30\%), poor (40\%), very poor (13.33\%) to unsuitable (3.33\%) for drinking purpose. Most locations with good APC do not translate into locations with good water quality syndicating a non-direct relationship between APC and groundwater quality for drinking purpose in the study area.
\end{abstract}

Keywords Groundwater · Maastrichtian · Sandstones · Longitudinal conductance $\cdot$ Aquifer protective capacity · Corrosivity $\cdot$ Lafia

\section{Introduction}

Groundwater exists in the interstices of soils or weathered/ fractured rocks (geologic formation) known as aquifers. Groundwater is usually clean and free from contaminants compared to surface water, and thus widely applied for domestic and industrial usage because its chemical and biological characteristics are fairly constant and require minimal treatment (Offodile 2014). The importance of groundwater to man's existence is immeasurable; it plays a great role in crop production, sanitation, domestic and industrial activities needed for survival. Overtime, however, the quality of groundwater has deteriorated owing to over-stretching of the aquifer through water milling, movement of leachates from dumpsites into the aquifer, leakage from surface and underground storage, salt water intrusion, oil spillage, mining activities, sewage from latrines, underlined petroleum pipes and septic tanks (Makeig 1982). The need to develop

Nuhu Degree Umar

degree.umar.pg76650@unn.edu.ng

1 Department of Geology, University of Nigeria, Nsukka, Nigeria mechanism for managing and protecting such vital resource cannot be over-emphasized.

In Nigeria, groundwater accounts for over $80 \%$ of the domestic water supply, largely due to its lower cost of development (Offodile 2014) and probably because of its proximity to the final consumers. In order to meet up with the growing water demand and to ensure sustainable access to safe and adequate clean water, there is the need to not only develop groundwater resources but to also protect it from contamination. The susceptibility of groundwater to contamination from other sources depends largely on the permeability, porosity, and overburden thickness of geologic formations (Obiora et al. 2015).

The application of geophysical methods, especially VES, for hydrogeological site characterization has increased in the last decade (Vereecken et al. 2004; Herckenrath et al. 2013, Mosuro et al. 2017). It is widely used due to portability of equipment, rapid measurements and lesser ambiguities in data interpretation; it is also an environmentally friendly (non-destructive) method (Todd and Mays 2005, Adeniji et al. 2014) and has been applied to solve hydrogeologicalrelated problems (Faneca Sa`nchez et al. 2013; Burschil et al. 2012). 
Mosuro et al. (2017) assessed groundwater vulnerability to leachate infiltration using electrical resistivity method and concluded that aquifers around the dumpsites have poor protective capacity and are prone to leachate contamination. Obiora et al. (2015) used electrical resistivity method and evaluated the aquifer protective capacity and soil corrosivity in Makurdi, Benue state. They identified areas where industries can be sited and iron pipes can be laid in order to safeguard the hydrological settings. Adeniji et al. (2014) evaluated soil corrosivity and aquifer protective capacity employing geo-electrical investigation in Bwari Basement Complex area, Abuja and characterized the area into zones of good, moderate, weak and poor aquifer protective capacity. However, Abiola et al. 2009, Atakpo and Ayolabi 2009, Ehirim and Nwankwo 2010 and Akana et al. 2016 who studied aquifer protective capacity did not correlate the rate of vulnerability of an aquifer to its groundwater quality for drinking purpose. Since aquifer protective capacity (APC) is the ability of the overburden unit to retard and filter percolating ground surface-polluting fluid into the aquifer units (Adeniji et al. 2014), there is need to evaluate the groundwater quality and establish whether areas of high APC correspond to areas of excellent or good water for drinking purpose and vice versa. This work will employ electrical resistivity techniques to delineate the aquifer protective units of the Maastrichtian sandstone aquifers of the Central Benue
Trough, and also characterize the groundwater hydrochemical characteristics. The aim is to identify zones with good aquifer protection, good water and noncorrosive areas for burying of service pipes. This is considering the growing population and increased groundwater exploration in Lafia and its environs and the imperative for sustainable groundwater management and to ensure access to safe and adequate water.

\section{Location, geology and hydrogeology of the study area}

The study area Lafia, which is the state capital of Nasarawa State, northcentral Nigeria is located within latitude $8^{\circ} 18^{\prime} \mathrm{N}$ to $8^{\circ} 42^{\prime} \mathrm{N}$ and longitude $8^{\circ} 18^{\prime} \mathrm{E}$ to $8^{\circ} 48^{\prime} \mathrm{E}$. Major localities within the study area include Lafia, Doma, Shabu, Assakio, Gandu, Agode, Alizaga, Mada, Major-Musa, Obi and Yelwa Doma (Fig. 1). The study area is characterized by two distinct seasons (wet and dry), with mean annual rainfall and temperature of $1250 \mathrm{~mm}$ and $28.5^{\circ} \mathrm{C}$, respectively.

It lies within Central Benue Trough, Nigeria, and characterized by ferruginized sandstones, red loose sands, flaggy mudstones, clays and claystones. Geologically, it is underlain by the Lafia Sandstones which are the youngest in the Central Benue Trough, Nigeria, and deposited under

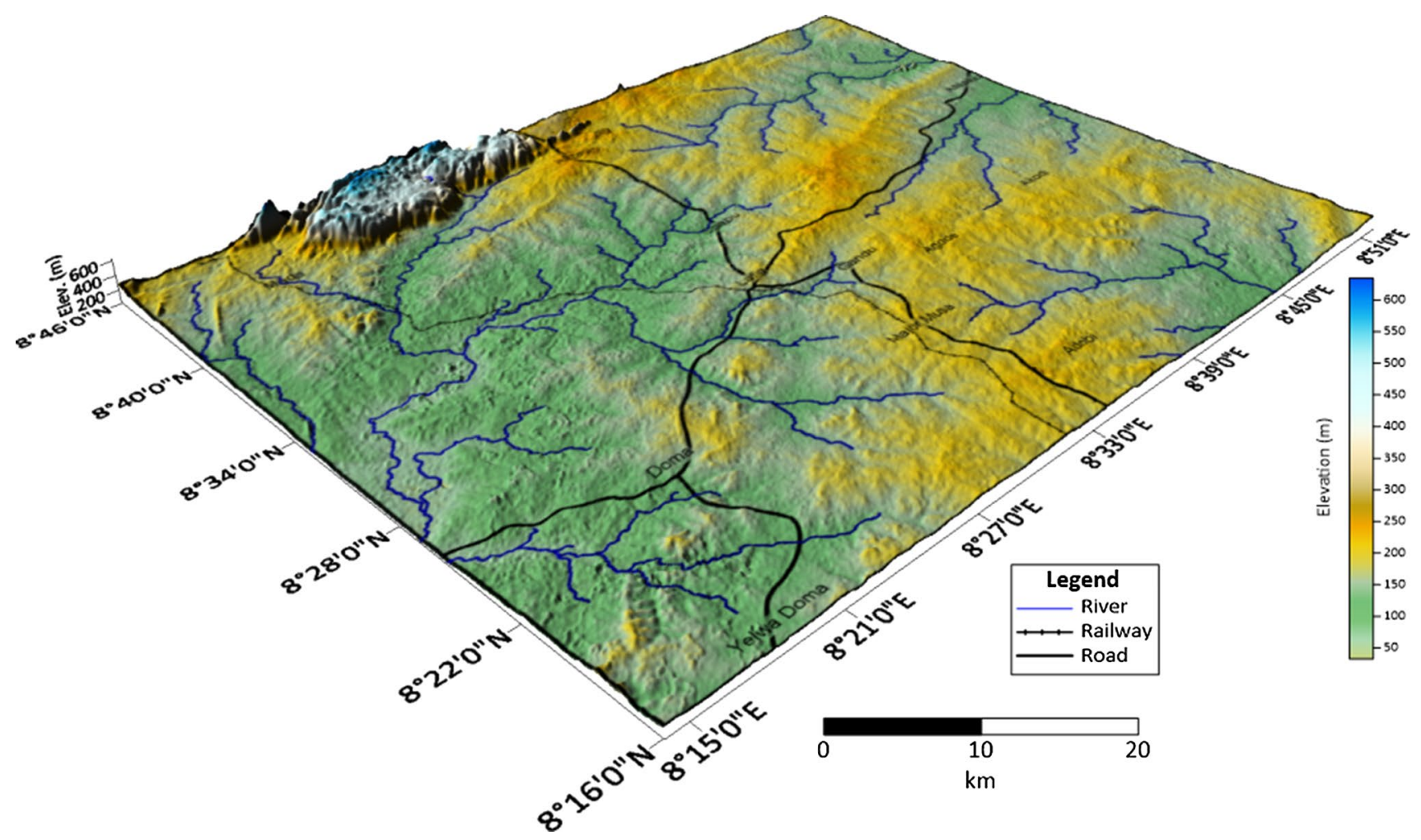

Fig. 1 3D Topographic map of the study area 
continental (fluvitial) condition in the Maastrichtian (Fig. 2) and lies uncomfortably on the Awgu Formation.

Hydrogeologically, the Lafia Formation comprises mainly fine-to-coarse grain sandstones, which are highly porous and permeable (Umar et al. 2018) and unarguably, the most prolific in the Central Benue Trough. The thickness of the sandstone aquifer is established to be around $150 \mathrm{~m}$ (Offodile 2014).

\section{Materials and methods}

Investigation was conducted into the subsurface using ABEM SAS 1000 Terrameter. VES technique employing the Schlumberger electrode configuration was used for data acquisition. This involves the injection of measured lowfrequency direct current (DC) into the subsurface via a pair of current electrode (AB) and measuring the corresponding voltage drop via another pair of potential electrode (MN).
The depth of penetration is proportional to the separation between the current electrodes in homogeneous subsurface, while varying the electrodes separation provides information about the stratification of the ground (Dahlin 2001; Obiora et al. 2015). Current electrode spacing ( $A B / 2)$ varied from $1 \mathrm{~m}$ to $400 \mathrm{~m}$, while potential electrode separation was varied between $0.5 \mathrm{~m}$ and $25 \mathrm{~m}$. The apparent resistivity was computed using (Ibuot et al. 2013):

$\rho a=\pi \frac{(A B / 2)-(M N / 2)}{M N} \cdot R a$

where $\rho a$ is the apparent resistivity, $A B$ is the distance between the two current electrodes, $M N$ is the distance between the potential electrodes and $R a$ is the apparent electrical resistance measured.

Each apparent resistivity value computed from the above equation was plotted on a log-log graph to the corresponding current electrode spacing, from which the layer resistivities, depths, thicknesses and curve types were deduced. The

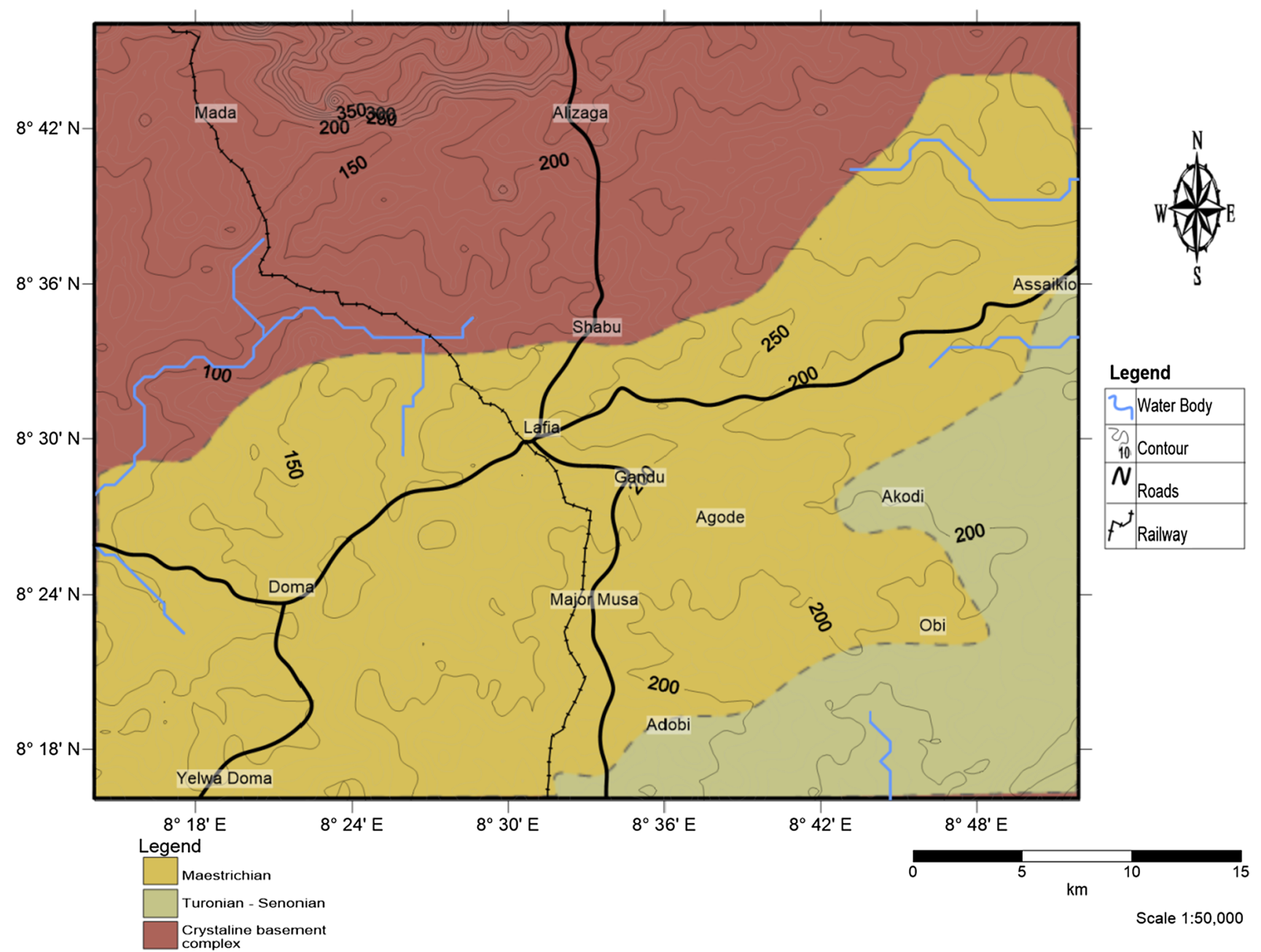

Fig. 2 Geologic map of the study area 
Table 1 Summary of layers resistivity, thickness and APC

\begin{tabular}{|c|c|c|c|c|c|c|c|c|c|c|}
\hline \multirow[t]{2}{*}{ VES points } & \multicolumn{5}{|c|}{ Layer resistivity (ohm) } & \multicolumn{4}{|c|}{ Layer thickness (m) } & \multirow[t]{2}{*}{ APC } \\
\hline & $\rho 1$ & $P 2$ & $P 3$ & $P 4$ & $P 5$ & $h 1$ & $h 2$ & $h 3$ & $h 4$ & \\
\hline 1 & 715 & 73.75 & 41.67 & 25.71 & & 7.5 & 7.5 & 52.5 & & 1.38 \\
\hline 2 & 2073.89 & 555.25 & 37.33 & 29.29 & & 10 & 25 & 65 & & 1.79 \\
\hline 3 & 721.2 & 794 & 273.83 & 316.8 & & 15 & 20 & 60 & & 0.27 \\
\hline 4 & 534 & 836.71 & 3441.8 & 724.5 & & 4 & 11 & 49 & & 0.04 \\
\hline 5 & 449.67 & 1725.33 & 448.13 & 235 & & 3 & 9.5 & 50.5 & & 0.13 \\
\hline 6 & 136 & 18.25 & 30.83 & 11.2 & & 3 & 47 & 53 & & 4.32 \\
\hline 7 & 773 & 191.6 & 42.17 & 56.6 & 2.29 & 7 & 38 & 47 & & 1.78 \\
\hline 8 & 2446.4 & 1983.6 & 317.72 & & & 8.5 & 36.5 & 163.5 & & 0.54 \\
\hline 9 & 682.4 & 783.17 & 635.13 & 410.8 & & 12.5 & 32.5 & 67.5 & & 0.17 \\
\hline 10 & 989.83 & 1952.4 & 2602 & 2927.9 & & 7 & 38 & 52 & & 0.05 \\
\hline 11 & 573.3 & 1656.1 & 3338.1 & 1444.7 & & 3.5 & 31.5 & 58.5 & & 0.04 \\
\hline 12 & 759.7 & 1663.7 & 3647.2 & 4605.6 & 1455 & 3.5 & 11.5 & 38.5 & 61.5 & 0.04 \\
\hline 13 & 657.9 & 1150 & 1266.9 & 2032 & & 8.5 & 41.5 & 58.5 & & 0.10 \\
\hline 14 & 858.5 & 1046 & 1355.2 & 2117.8 & & 6.5 & 63.5 & 86.5 & & 0.13 \\
\hline 15 & 1304.9 & 1528 & 333.5 & 1491.1 & & 12.5 & 22.5 & 67.5 & & 0.23 \\
\hline 16 & 401 & 316.2 & 92.22 & 12 & & 12.5 & 32.5 & 117.5 & & 1.41 \\
\hline 17 & 369 & 436.2 & 131.1 & 18.6 & & 6.5 & 43.5 & 56.5 & & 0.55 \\
\hline 18 & 355.8 & 399.4 & 99.4 & 18.2 & & 12.5 & 32.5 & 67.5 & & 0.80 \\
\hline 19 & 590.6 & 936.3 & 360 & 130 & & 15.5 & 49.5 & 50.5 & & 0.22 \\
\hline 20 & 335 & 161 & 12.7 & 10.5 & & 6.5 & 8.5 & 91.5 & & 7.28 \\
\hline 21 & 250.9 & 107.4 & 66.3 & 17 & & 8.5 & 41.5 & 58.5 & & 1.30 \\
\hline 22 & 199.8 & 171.2 & 157.3 & 101 & & 5.5 & 9.5 & 25.5 & & 0.25 \\
\hline 23 & 895.7 & 491.1 & 424.8 & 340.7 & & 8.5 & 36.5 & 43.5 & & 0.19 \\
\hline 24 & 903.7 & 1432.8 & 2122.2 & 3090 & & 6.5 & 38.5 & 111.5 & & 0.089 \\
\hline 25 & 110 & 56 & 16.25 & 119 & & 6.5 & 15 & 90 & & 5.87 \\
\hline 26 & 424.7 & 103 & 30.3 & 10.16 & & 6.5 & 24 & 76 & & 2.76 \\
\hline 27 & 802.3 & 524.2 & 130.5 & 31.14 & & 8.5 & 17 & 73 & & 0.60 \\
\hline 28 & 266.3 & 64 & 28.8 & 13.4 & & 8.5 & 36.5 & 48.5 & & 2.29 \\
\hline 29 & 164.1 & 320.1 & 198.3 & 1388.2 & & 3.5 & 18 & 142 & & 0.80 \\
\hline 30 & 846.5 & 861.6 & 560.4 & 2177.4 & & 3.5 & 11.5 & 148.5 & & 0.28 \\
\hline 31 & 348.2 & 913.8 & 1791.6 & 1718.2 & & 3.5 & 18 & 142 & & 0.11 \\
\hline 32 & 148.8 & 96.54 & 193.8 & 1090.8 & & 14.5 & 85.5 & 99.5 & & 1.50 \\
\hline 33 & 244.9 & 247.2 & 173 & 1065.8 & & 3.5 & 18 & 232 & & 1.43 \\
\hline 34 & 446.2 & 66.2 & 89.2 & 1760 & & 10.5 & 89.5 & 125.5 & & 2.78 \\
\hline 35 & 44.7 & 71.2 & 252.3 & 961.9 & & 4.8 & 16.7 & 123.3 & & 0.83 \\
\hline 36 & 882.3 & 2304.8 & 2411.3 & 2110 & & 6.8 & 63.2 & 121.8 & & 0.09 \\
\hline 37 & 853.1 & 1494.1 & 1594 & 1783.5 & & 6.8 & 63.2 & 121.8 & & 0.13 \\
\hline 38 & 60.3 & 162.5 & 300.6 & 1400.8 & & 3.5 & 29 & 131 & & 0.67 \\
\hline 39 & 1582.7 & 274.3 & 1045.8 & 226.4 & 1091.5 & 6.8 & 25.7 & 74.3 & 175.7 & 0.95 \\
\hline 40 & 4213.3 & 2781.8 & 3299.8 & 3539.3 & 4.5 & 44 & 96 & 0.04598 & & 0.05 \\
\hline 41 & 65.99 & 34.8 & 74.8 & 1715.4 & & 2.9 & 29.6 & 110.4 & & 2.37 \\
\hline 42 & 734.9 & 183.7 & 711.97 & 1710.8 & & 10.5 & 89.5 & 95.5 & & 0.64 \\
\hline 43 & 70.28 & 254.8 & 1379.44 & 1651 & & 21.5 & 78.5 & 106.5 & & 0.70 \\
\hline 44 & 596.2 & 121.5 & 629.8 & 1778.3 & & 6.8 & 41.7 & 98.3 & & 0.51 \\
\hline 45 & 595.7 & 759.3 & 201.6 & 64.57 & & 12.5 & 22.5 & 47.5 & & 0.29 \\
\hline
\end{tabular}




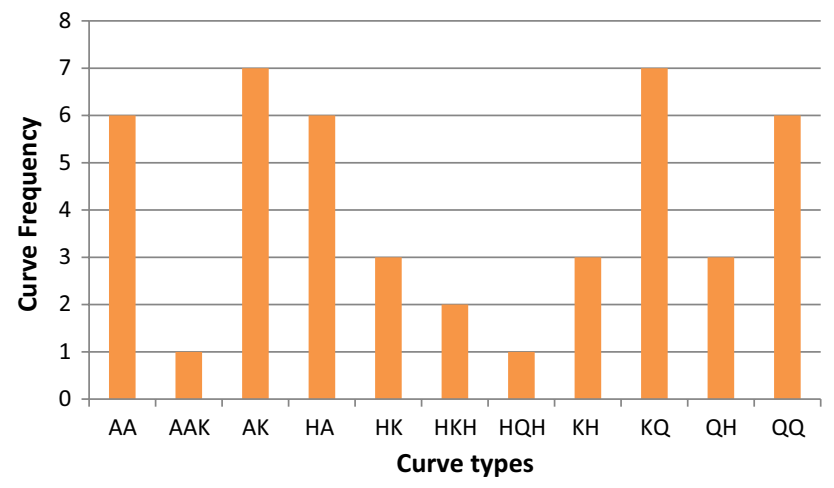

Fig. 3 Frequency distribution of curve types

conventional quantitative interpretation using partial curve matching was done by matching the field curves with the auxiliary curves. Computer modelling software IPI2win was used in the inversion and iteration of each VES point from which the resistivities and thicknesses of the layers were improved (Fig. 4).

The total longitudinal conductance $\left(S_{\mathrm{T}}\right)$ of the overburden unit at each vertical electrical sounding station was obtained from the mathematical relation (Zohdy et al. 1974):

$S_{\mathrm{T}}=\sum_{i=1}^{n} \frac{h_{i}}{\rho_{i}}$

where $S_{\mathrm{T}}=$ total longitudinal conductance of the overburden, $\rho_{i}=$ layer resistivity, $h_{i}=$ layer thickness and $n=$ number of layers and was used to categorize the aquifer protective capacity of the study area.

Soil corrosivity was determined by comparing the resistivity value of the first layer on each VES point with the corrosivity rating (Baeckmann and Schwenk 1975; Agunloye 1984; Oladapo et al. 2004). The hydrogeochemical characteristics of groundwater in the study area were evaluated to ascertain the correlation/relationship between aquifer protection and vulnerability to groundwater quality. Thirty (30) groundwater samples, two from each location, were collected from wells and boreholes around the vicinity where VES was conducted, in order to characterize its hydrogeochemical properties. The measurement of electrical conductivity (EC), total dissolved solids (TDS) and static water levels (SWL) was carried out in situ using SOLINT temperature, level and conductivity (TLC) dip metre. The water samples were analysed for anions and cations. Ultra violet (UV) spectrophotometer and flame analysis were used for the detection of anions $\left(\mathrm{SO}_{4}{ }^{2-}, \mathrm{Cl}^{-}, \mathrm{NO}_{3}{ }^{-}\right.$and $\left.\mathrm{HCO}_{3}{ }^{2+}\right)$, while atomic absorption spectrometer (AAS), titrimetric and colorimetric methods were used in cations $\left(\mathrm{Na}^{+}, \mathrm{K}^{+}\right.$, $\mathrm{Ca}^{2+}, \mathrm{Mg}^{2+}, \mathrm{Fe}^{3+}, \mathrm{Mn}^{2+}$ and $\mathrm{Pb}^{2+}$ ) detection. Results were computed and analysed to obtain the water quality index (WQI) of each sample, from which its quality for drinking purpose was ascertained. The WQI was computed using (Ramakrishnaiah et al. 2009).

$\mathrm{WI}=\frac{w i}{\sum_{i=1}^{n} w i}$

where $\mathrm{WI}=$ relative weight, $w i=$ weight of each parameter and $n=$ number of parameters.

The concentration of each parameter in groundwater sample was divided by its corresponding WHO standard and estimated as a percentage to obtain its quality rating (QI) (Gebrehiwot et al. 2011)

$\mathrm{QI}=(C i / S i) \times 100$

where $\mathrm{QI}$ is the quality rating, $C i$ is the concentration of each parameter in a water sample and $\mathrm{Si}$ is the WHO drinking water standard for each parameter.

The WQI is computed by summing the SI (sub-index) determined for each parameter (Reza and Singh 2010).

$\mathrm{SI}=\mathrm{WI} \times \mathrm{QI}$

$\mathrm{WQI}=\sum \mathrm{SI}$

Based on the WQI value, groundwater is classified into zones of excellent water, good water, permissible water, poor water, very poor water or water unsuitable for drinking purpose.

\section{Results and discussions}

\section{Electrical resistivity}

Summary of the results from the 45 VES points is presented in Table 1. From the VES interpreted results, four geo-electric layers were delineated in all locations except in VES 7, 12 and 39 having five geo-electrical layers. The subsurface layers delineated are topsoil/laterite, sandy clay, clayey sand, sandstone and shale having a resistivity range of 44.7-4213.3 $\Omega \mathrm{m}, 18.25-2781.8 \Omega \mathrm{m}, 12.7-3647 \Omega \mathrm{m}$, $10.16-4605.6 \Omega \mathrm{m}$ and $2.29-1455 \Omega \mathrm{m}$, respectively, and the thicknesses ranging from 2.9 to $21.5 \mathrm{~m}, 7.5$ to $89.5 \mathrm{~m}, 25.5$ to $232 \mathrm{~m}$ and 61.5 to $175.7 \mathrm{~m}$, respectively. The topsoil is the 
(a)

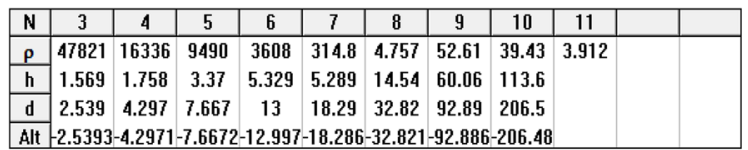

RMS $1.97 \%$

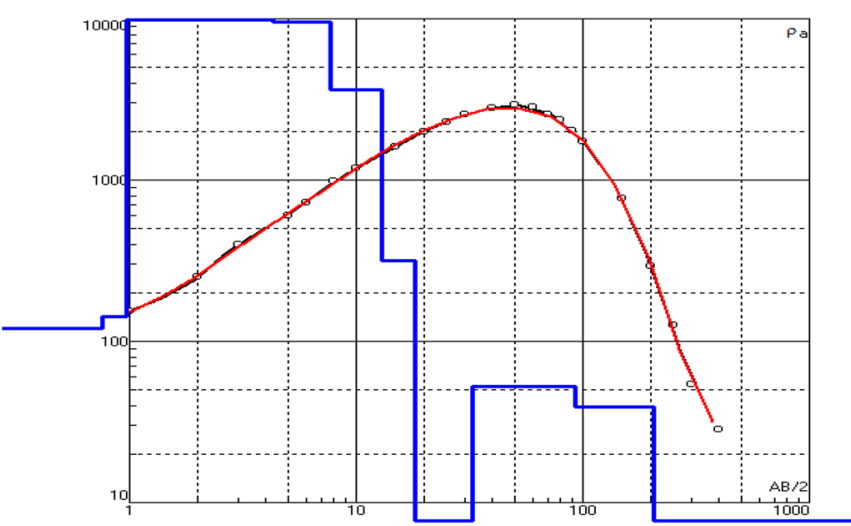

(b)

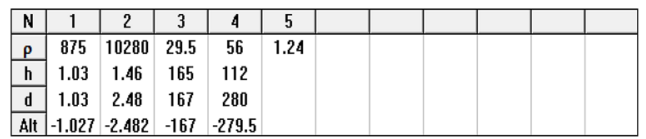

RMS $3.79 \%$

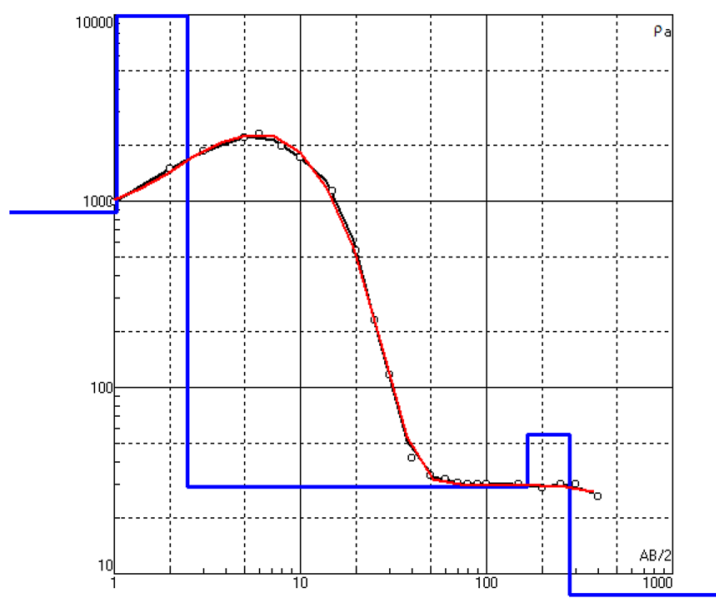

(c)

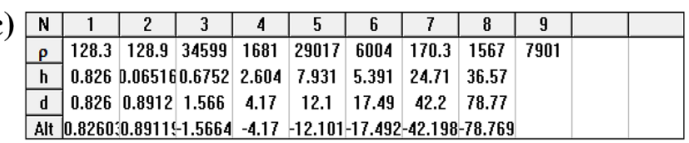

RMS 1.97

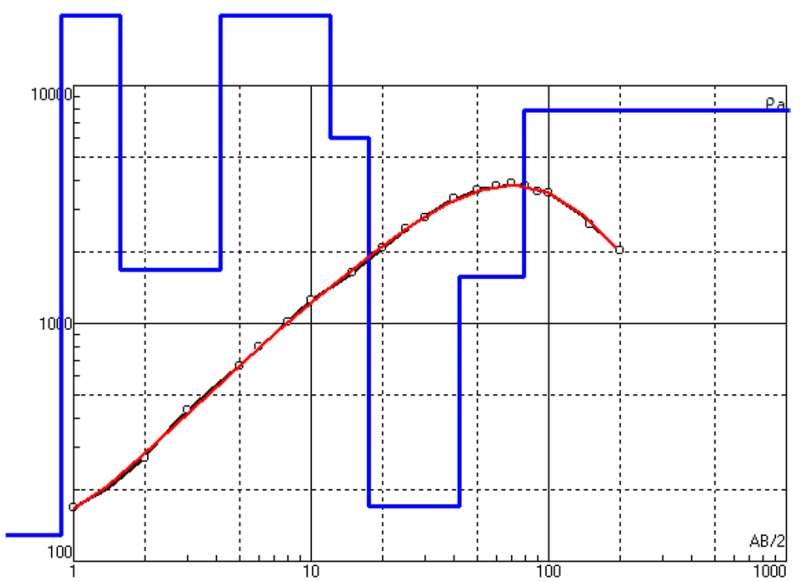

(d)

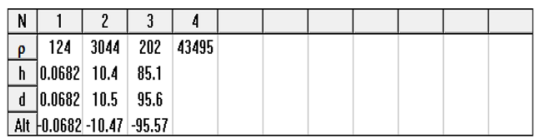

RMS 4.1

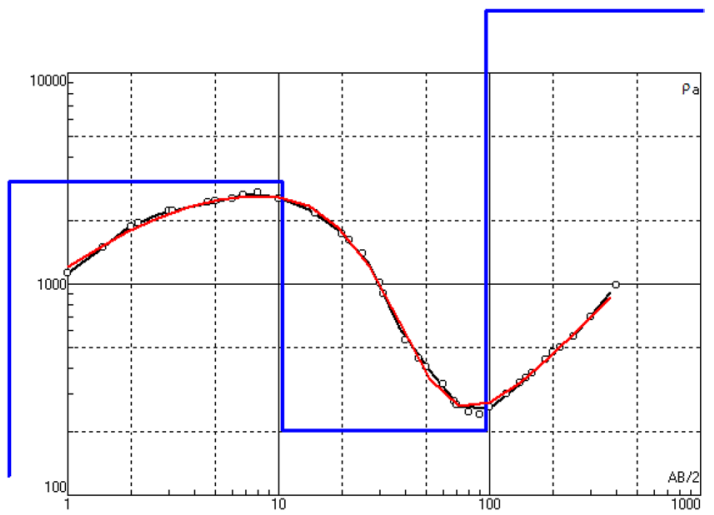

Fig. 4 a Resistivity curve for VES 3 (AK type). b Resistivity curve for VES 1 (KQ type). c Resistivity curve for VES 4 (AAK type). d Resistivity curve for VES 9 (HQH type). e Resistivity curve for VES 2. f Resistivity curve for VES 6

thinnest around the central part with a thickness of $2.9 \mathrm{~m}$, and thickest around the north-eastern part with a thickness of $21.5 \mathrm{~m}$. The lowest resistivity $(44.7 \Omega \mathrm{m})$ for the topsoil was recorded at VES 35, while at VES 40 it was highly resistive $(4213.3 \Omega \mathrm{m})$. The weathered sandstone is identified as the aquiferous zone with thickness varying between 25.5 and $175.7 \mathrm{~m}$ (thickest at VES station 39 and thinnest at
VES station 22). The thinnest part of the aquifer (VES 22) lies close to the boundary between Lafia Formation and the Awgu Formation, while the thickest part (VES 39) lies at the central part of the study area (Fig. 2). Eleven (11) curve types were deduced (Fig. 3), with the AK type (Fig. 4a) and KQ type (Fig. 4b) as the dominant curve types constituting $16 \%$ each, while the AAK type (Fig. 4c) and HQH type 
(e)

\begin{tabular}{|c|c|c|c|c|c|c|c|c|c|c|c|}
\hline $\mathrm{N}$ & 1 & 2 & 3 & 4 & 5 & & & & & & \\
\hline $\mathrm{p}$ & 383 & 16746 & 132 & $\mathbf{8 2 4}$ & 24 & & & & & & \\
$\mathrm{yh}$ & 1.41 & 1.91 & $\mathbf{8 . 0 3}$ & 26.7 & & & & & & & \\
\hline $\mathrm{d}$ & 1.41 & 3.32 & 11.3 & 38.1 & & & & & & & \\
\cline { 1 - 5 } & -1.408 & -3.316 & -11.35 & -38.09 & & & & & & & \\
\hline
\end{tabular}

RMS 3.5\%

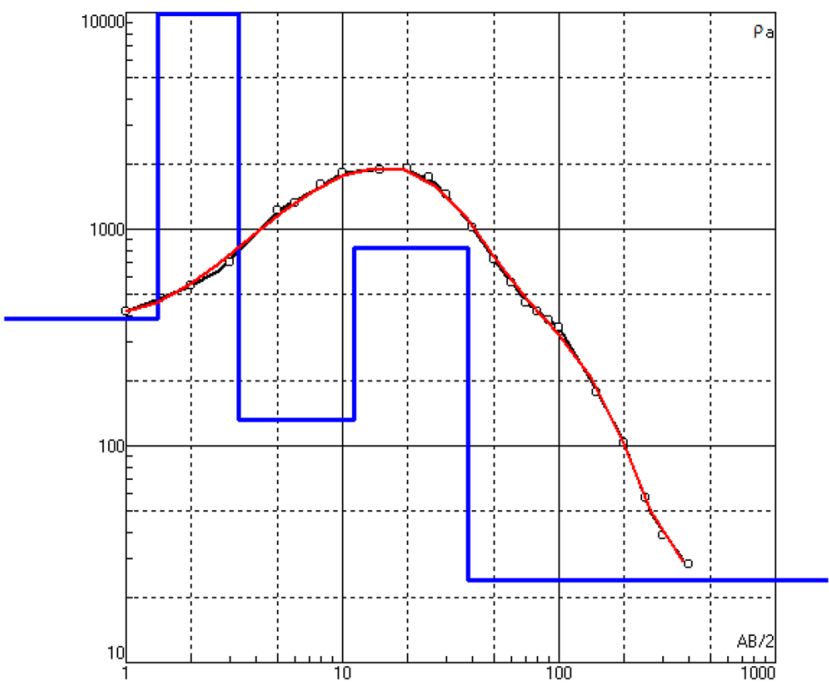

Fig. 4 (continued)

(Fig. 4d) are the least curve types, with 2\% each. Variation in curve types within the study area implies changes in the subsurface lithologies (Oladapo et al. 2004; Adeniji et al. 2014).

Litho-logs from existing and nearby boreholes were compared with the geo-electric layers and thicknesses of the subsurface inferred from VES conducted close to the boreholes (Fig. 5a-e). The borehole litho-logs were established by examining recovered cores during drilling. Strong correlations exist between the geo-electric layers, thicknesses and the number of layers except in VES 2 which showed a slight variation (Table 2).

\section{Aquifer protective capacity}

Using the first-order geo-electric parameters (inferred thicknesses and resistivities) of the overburden, the longitudinal conductance (Da Zarouk parameters) was estimated and used to classify the APC of the study area (Adeniji et al. 2014; Obiora et al. 2015; Mosuro et al. 2017). The longitudinal conductance $\left(\mathrm{S}_{T}\right)$ values range from 0.04 to $7.28 \mathrm{mho}$. The higher values of $S_{T}(4.32,5.87$ and $7.28 \mathrm{mho})$ were obtained at VES 6, 20 and 25 corresponding to Madagba, Ashigye and Maraba Akunza areas, respectively (Fig. 5), while the least value $(0.04 \mathrm{mho})$ was recorded at VES station (f)

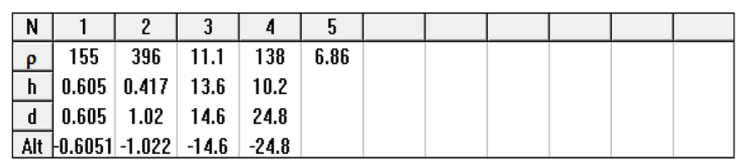

RMS $3.44 \%$

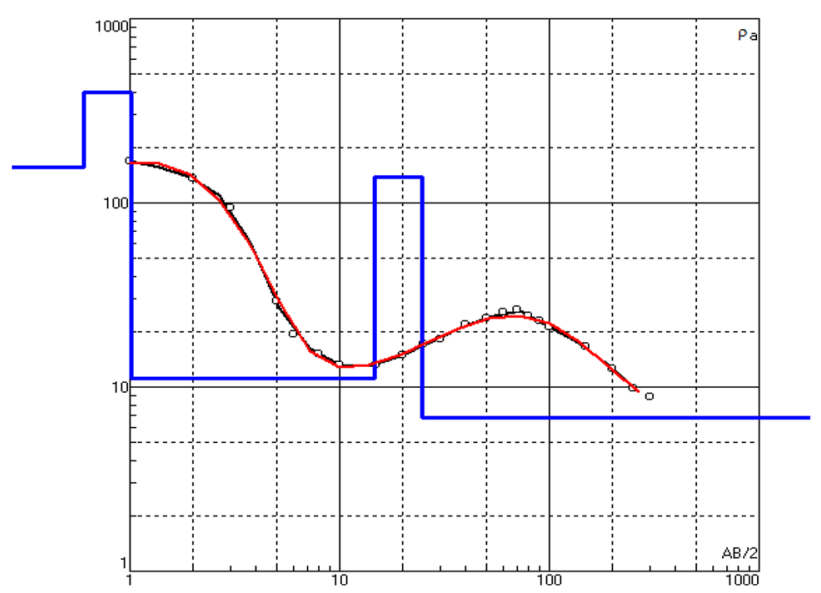

12 (Araho). Correlating the $\mathrm{S}_{T}$ values with APC rating (Henriet 1976; Oladapo et al. 2004) in Table 3 revealed that the study area has $4 \%, 36 \%, 29 \%$ and $31 \%$ corresponding to "very good", "good", "moderate" and "poor-to-weak" APC, respectively. The $69 \%$ of aquifers covered by very good to moderate APC in Lafia is greater than that reported by Umar et al. (2018) for Awe which is also within the Central Benue Trough.

Generally, groundwater in the southern, south-western and central regions is more susceptible to contaminations than that in the northern, eastern and south-eastern regions because the former is dominated by low APC, while the latter is dominated by high APC. An effective groundwater protection is provided by protective layers with sufficient thickness and low hydraulic conductivity leading to high residence time of percolating water (Adeniji et al. 2014).

Areas of high longitudinal conductance (thick overburden and low resistivity) constitute regions of very good (Ashigye and Mararaba Akunza) to good APC (Shabu, Gandu, Madagba, Rutu, Akunza, Kwangwa and Federal University Lafia). In the event of oil spillage, leaky underground tanks, waste or petroleum pipes breakage, the aquifers in this region have sufficient seal from pollution (Adeniji et al. 2014), and as such groundwater 
(a)

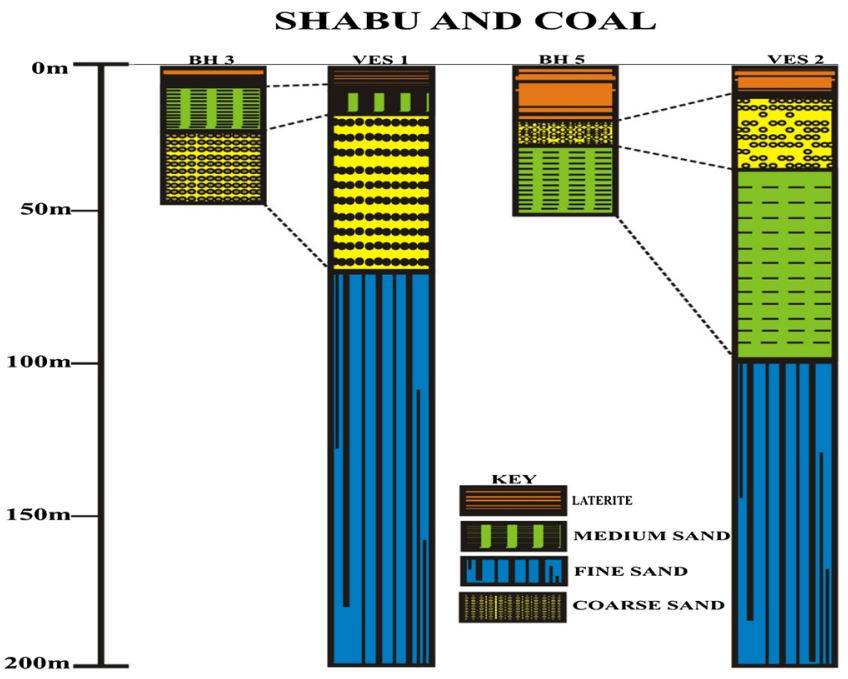

(b)

\section{Lower Benue And Assakio}

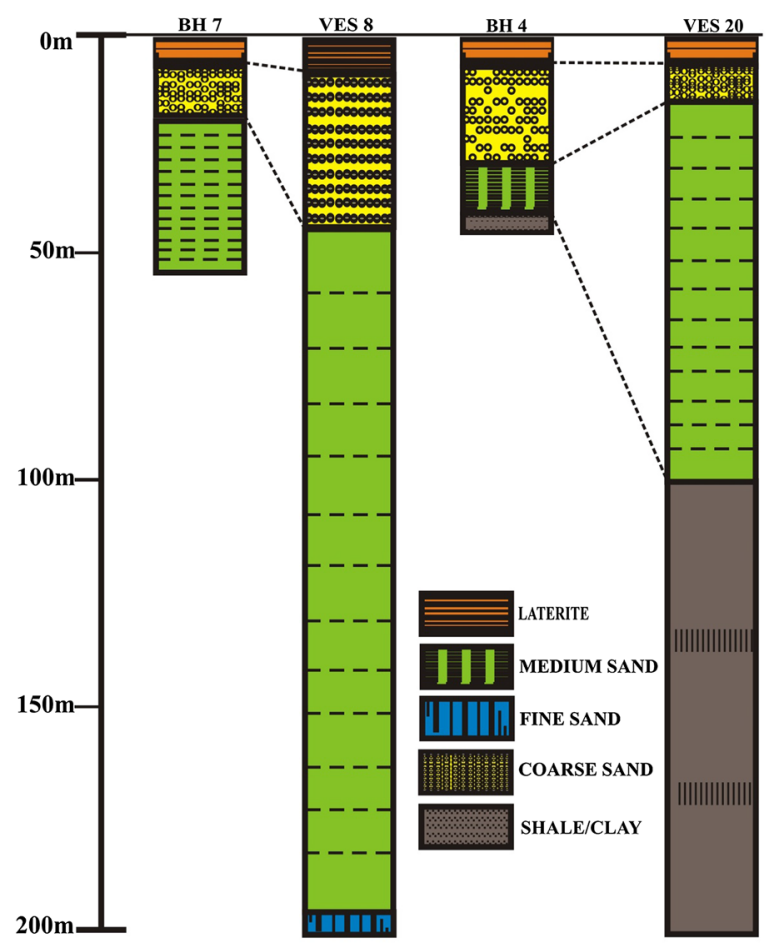

Fig. 5 a Lithologic correlation of borehole log and VES-inferred layers (VES 1 and VES 2). b Lithologic correlation of borehole log and VES-inferred layers (VES 8 and 20). $\mathbf{c}$ Lithologic correlation of bore- (c)

\section{Lafia New mrkt and Kilema}

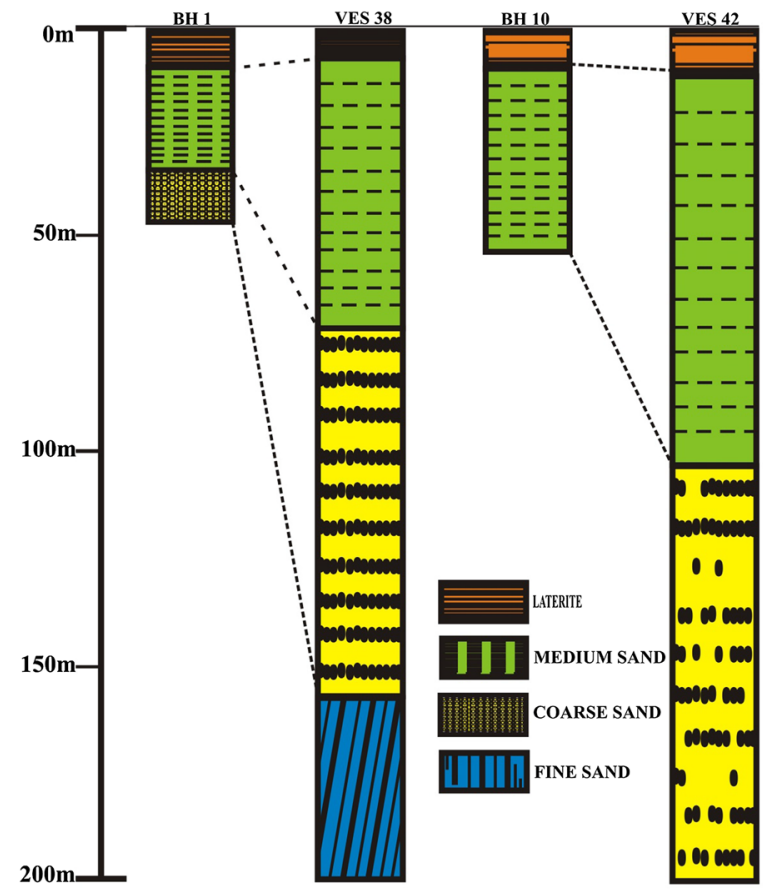

(d)

500 Housing And Oriya Farm

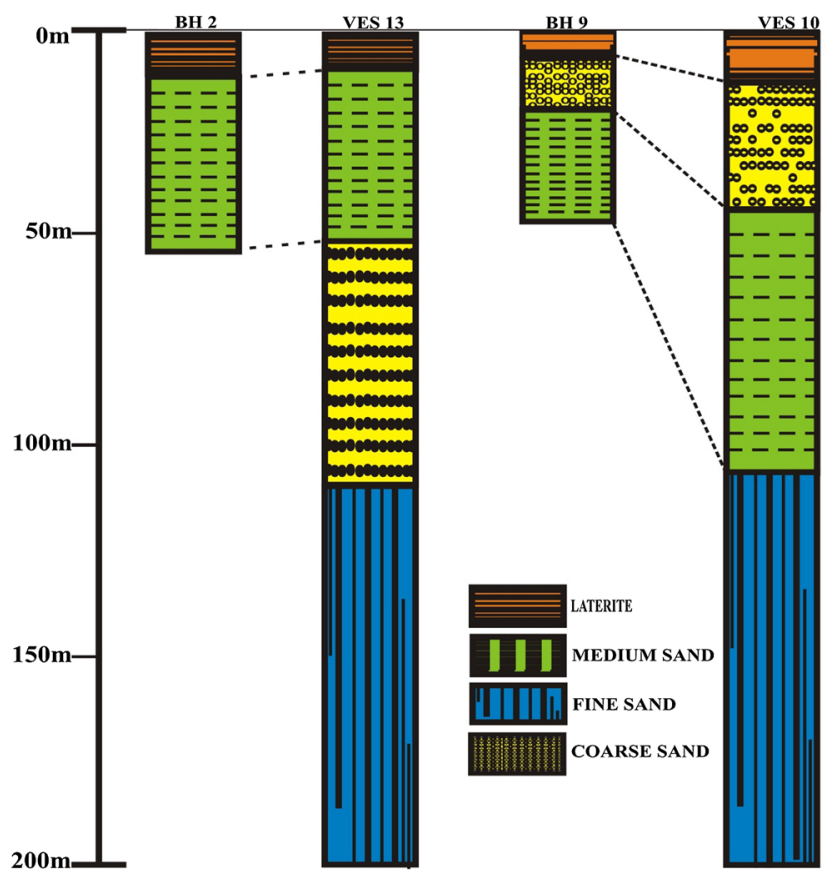

hole log and VES-inferred layers (VES 38 and 42). d Lithologic correlation of borehole log and VES-inferred layers (VES 13 and 10) 
Table 2 Longitudinal conductance (mho) and aquifer protective capacity rating

\begin{tabular}{llcl}
\hline Si (mho) & $\begin{array}{l}\text { APC rating. Henriet (1976) and } \\
\text { Oladapo et al. (2004) }\end{array}$ & Percentage (\%) & VES points \\
\hline$>10$ & Excellent & & \\
$5-10$ & Very good & 4.44 & 20,25 \\
$0.7-4.49$ & Good & 35.56 & $1,2,6,7,16,18,21,26,28,29,32,33,34,35,39,41$ \\
$0.2-0.69$ & Moderate & 28.90 & $3,8,15,17,19,22,27,30,38,42,43,44,45$ \\
$<0.1-0.19$ & Poor-weak & 31.10 & $4,5,9,10,11,12,13,14,23,24,31,36,37,40$ \\
\hline
\end{tabular}

Table 3 Soil corrosivity ratings (Agunloye 1984; Oladapo et al. 2004; Mosuro et at. 2017)

\begin{tabular}{lll}
\hline $\begin{array}{l}\text { Soil resistivity } \\
(\Omega \mathrm{m})\end{array}$ & Soil corrosivity & $\begin{array}{l}\text { Percentage } \\
\text { of samples }\end{array}$ \\
\hline$<10$ & Very strongly corrosive (VSC) & NIL \\
$10-60$ & Moderately corrosive (MC) & $4.5 \%$ \\
$60-180$ & Slightly corrosive (SC) & $13.33 \%$ \\
$>180$ & Practically noncorrosive (PNC) & $82.22 \%$ \\
\hline
\end{tabular}

Table 4 Summary of the hydrogeochemical analysis

\begin{tabular}{llll}
\hline Parameters & Mean & Max & Min \\
\hline $\mathrm{pH}$ & 53 & 7.3 & 5.1 \\
$\mathrm{EC}$ & 491.75 & 1396 & 110 \\
$\mathrm{TDS}$ & 73.72 & 136.9 & 3.4 \\
$\mathrm{NO}_{3}{ }^{-}$ & 3.16 & 5.41 & 0.97 \\
$\mathrm{PO}_{3}{ }^{-}$ & 0.27625 & 0.57 & 0.1 \\
$\mathrm{~K}^{+}$ & 0.146563 & 0.43 & 0.02 \\
$\mathrm{SO}_{4}$ & 0.084375 & 0.54 & 0.01 \\
$\mathrm{HCO}_{3}^{-}$ & 72.05625 & 134.2 & 24.4 \\
$\mathrm{Cl}^{-}$ & 0.1825 & 0.79 & 0.1 \\
$\mathrm{Ca}^{2+}$ & 0.289656 & 0.716 & 0.113 \\
$\mathrm{Mg}^{2+}$ & 0.134438 & 0.624 & 0.021 \\
$\mathrm{Fe}^{2+}$ & 3.20271 & 16.336 & 1.538 \\
$\mathrm{~Pb}^{2+}$ & 0.11425 & 0.497 & 0.1 \\
$\mathrm{Na}^{+}$ & 1.023813 & 9.23 & 0.1 \\
\hline
\end{tabular}

contamination could be a rare occurrence. Areas with moderate APC (Alawagana, Kilema, Kurikyo, Bukan Sidi, Akurba and Yelwa Doma) are less susceptible to pollution from anthropogenic sources, but may become vulnerable with high rate of pollution over time. These zones contain appreciable overburden thickness with clayey layers which serve as natural filter to percolating fluids. Groundwater in areas with weak APC (Gimare, Doma barrack, Oriya farm, Gidan Mangoro and Wakwa) and Poor APC (Kawo, Araho, 500 housing, and Doma) is susceptible to contaminations from anthropogenic sources or oil spillage. Atakpo and Ayolabi (2009) in their study recommended the conduct of hydrogeochemical analysis before consumption of water.

\section{Evaluation of soil corrosivity}

Since utility pipes for conveying water, hydrocarbons, waste and gas are buried within the topmost layer of the earth, the resistivity values of these layers were used in the evaluation of the corrosivity potential. From the VES results, the topsoil has a resistivity range of 44.7-4213.3 $\Omega \mathrm{m}$ (Table 1). Adopting Agunloye (1984), Oladapo et al. (2004), Mosuro et al. (2017) classification (Table 3), corrosivity within the study area ranged from "practically noncorrosive" to "moderately corrosive". Approximately, $82.22 \%$ of the study area is "practically noncorrosive", while the central and lower parts were "slightly corrosive" (13.33\%) to "moderately corrosive" $(4.5 \%)$ which correlates with the alkaline-rich water within this region as indicated by the $\mathrm{pH}$. Low $\mathrm{pH}$ increases corrosivity (WHO 2017), and therefore, steel pipes buried within the slightly to moderately corrosive parts (17.38\%) are more vulnerable to corrosion and eventual failure (Akintorinwa and Abiola 2011).

From the corrosivity potential computed, steel pipes, underground metal storage tanks and galvanized pipes can be buried in most parts of the study area without the risks of being ruptured, deteriorated, broken or leaked. These areas (Shabu, Assakio, Gandu, Agyaragu, Gimare, Akura, Akurba, Alawagana, Ashigye, Ugah and Wakwa) are rated as "practically noncorrosive". Areas around Akurba, Akunza Jarmai and Mararaba Akunza are rated as "slightly corrosive" and have low potential for corroding, rupturing or causing leakage of underground metal tanks or steel 

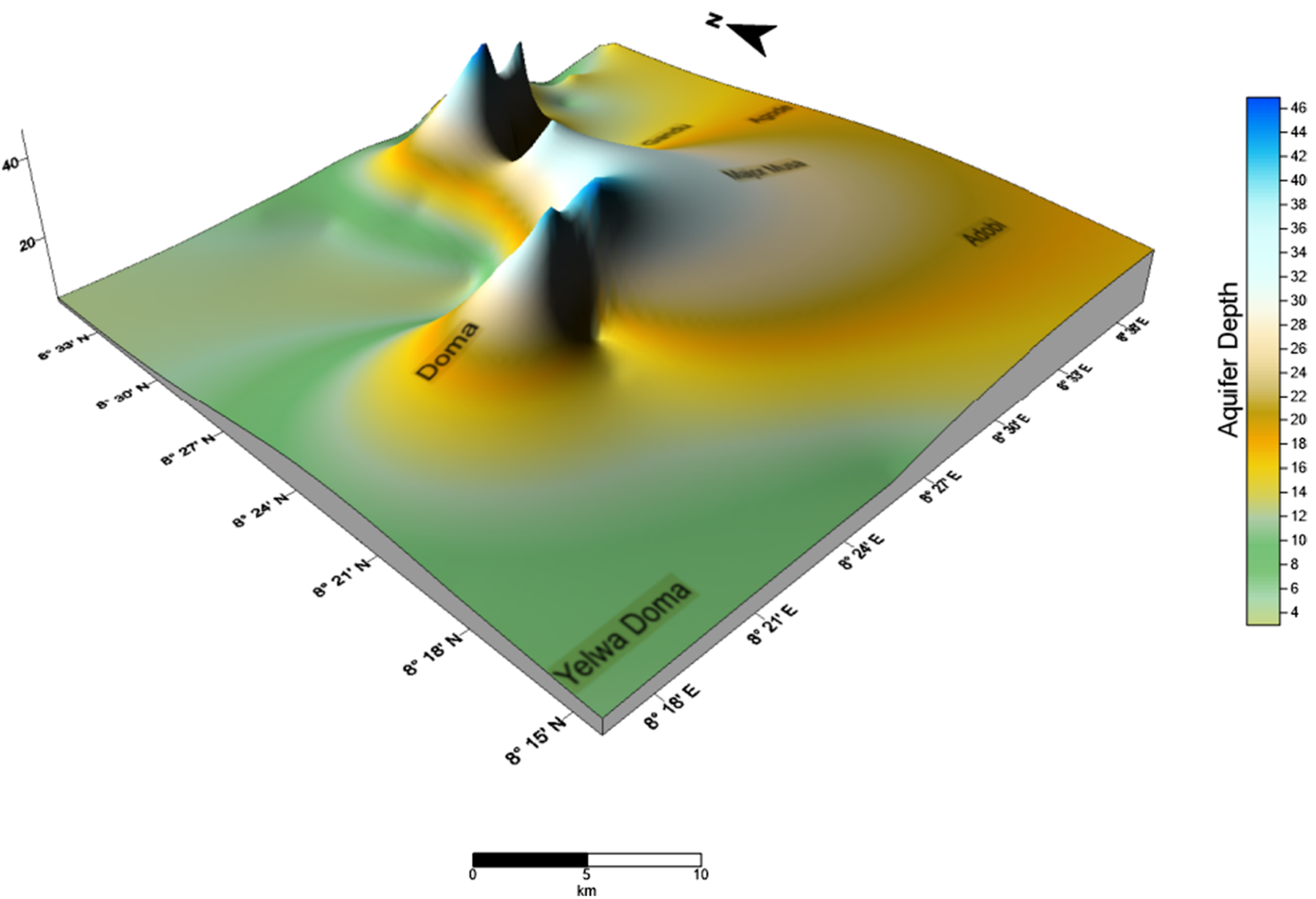

Fig. 6 3D Overburden thickness map of the study area

pipes, while areas around Federal University Lafia and Kilema have "moderate" corrosivity rating (Obiora et al. 2015). In these areas, plastic pipes should be used, and alternatively, concrete rings, pipes and underground reservoirs should be constructed for fluids storage and transfer.

\section{Groundwater chemistry and water quality index (WQI)}

Results of the hydrogeochemical analysis of 30 groundwater samples are summarized in Table 4 . The concentrations of the anions $\left(\mathrm{HCO}_{3}^{-}, \mathrm{NO}_{3}^{-}, \mathrm{Cl}^{-}, \mathrm{PO}_{3}{ }^{-}, \mathrm{SO}_{4}{ }^{2-}\right)$ varied between 24.4-134.2, 0.97-5.41, 0.1-0.79, 0.1-0.57 and 0.01-0.54 mg/l, respectively, while the cations $\mathrm{Fe}^{2+}$, $\mathrm{Na}^{+}, \mathrm{Ca}^{2+}, \mathrm{Mg}^{2+}, \mathrm{Pb}^{2+}$ and $\mathrm{K}^{+}$varied between 16.336, $9.23,0.716,0.624,0.497$ and $0.43 \mathrm{mg} / \mathrm{l}$, respectively (Table 4). The $\mathrm{pH}$ ranges from 5.1 to 7.3 implying an acidic to weakly alkaline water. Waters of moderate acidity denote the presence of chemicals from fertilizer sources and leaching of dissolved constituents into aquifer systems (Mgbenu and Egbueri 2019); however, there is no healthbased guideline value proposed for $\mathrm{pH}$ (WHO 2017). Some of the water samples slightly fall below WHO (2011) limit (6.2-8.5) for drinking water. Electrical conductivity EC and total dissolved solids TDS range from 110 to $1396 \mu \mathrm{S} /$ $\mathrm{cm}$ and 3.4-136.9 $\mathrm{mg} / \mathrm{l}$, respectively. Based on the TDS values (Fig. 6), groundwater in the study area can be classified as "freshwater" (Carrol 1962). About 63\% of the groundwater samples have EC within the WHO (2011) specified limit for drinking, while $37 \%$ have EC values above the limit. The concentration of all tested parameters falls within the WHO (2011) specification for drinking water except $\mathrm{Pb}^{2+}$ and $\mathrm{Fe}^{2+}$ (Fig. 7), with concentrations of 0.50 and $16.34 \mathrm{mg} / \mathrm{l}$, respectively, which deteriorate the 


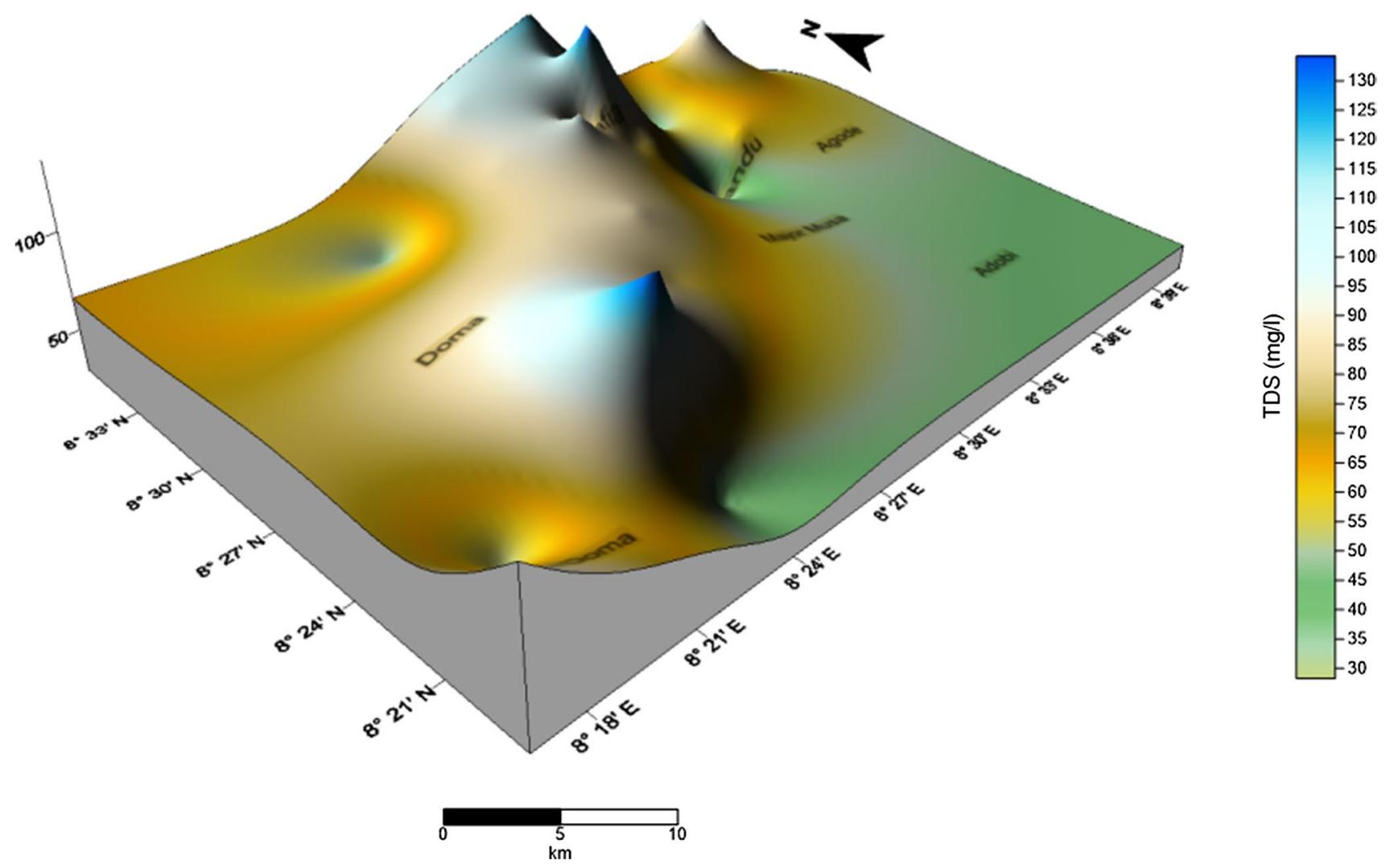

Fig. 7 3D TDS distribution map of the study area

water quality for drinking purpose. Leachates from dumpsite and anthropogenic sources control the concentration of $\mathrm{Pb}^{2+}$ (Tiwari et al. 2017; Egbueri 2018; Mgbenu and Egbueri 2019) and cause undesirable taste in beverages, stains on wares and laundry, slimy coatings and depositions in water reticulation pipes (WHO 2017; Mugbenu and Egbueri 2019). The high concentration of $\mathrm{Fe}^{2+}$ stem from the infiltration of iron-rich laterites by rainfall (Batabyal and Chakraborty 2015).

WQI characterized groundwater around Gandu, Shabu, College of Agric and Kurikyo as excellent waters. This implies that groundwater around this region will not require further treatment before drinking, as it is believed to be free of pollutions and impurities. Areas such as Ashigye, Ugah, Assakio, Agode, Adobi, Major Musa and Yelwa Doma are characterized by good waters for drinking purpose. Poor water and very poor water are concentrated around Lafia, 500 housing, Akura, Araho, Kilema, Alawagana, Akurba, Wakwa, Gimare, Angwan Nungu and Lafia new market, Bukan sidi, Oriya farm, Alwaza and Doma), respectively.
Groundwater in this region will require treatment before consumption, as it is prone to contamination (Fig. 8).

Using the WQI, groundwater in the study area varies from excellent water to water unsuitable for drinking purpose. Groundwater quality varied from excellent $(13.33 \%)$, good $(30 \%)$, poor $(40 \%)$, very poor $(13.33 \%)$ to water unsuitable (3.33\%) for drinking purpose (Table 5). Groundwater in the study area was characterized using Piper (1944) trilinear diagram. From the diagram, three water types were deduced; the $\mathrm{Ca}^{2+}+\mathrm{Mg}^{2+}$ water type, $\mathrm{Ca}^{2+}+\mathrm{Na}^{+}+\mathrm{K}^{+}$water type and $\mathrm{HCO}_{3}{ }^{-}+\mathrm{CO}_{3}{ }^{-}$water type (Fig. 9). The Types I $\left(\mathrm{Ca}^{2+}+\mathrm{Mg}^{2+}\right)$ and $\mathrm{II}\left(\mathrm{Ca}^{2+}+\mathrm{Na}^{+}+\mathrm{K}^{+}\right)$are the dominant water types.

However, some locations with good APC also contained excellent or good water, for example Ashige, Gandu and Shabu. However, most locations with good APC do not translate into locations with good groundwater quality for drinking purpose. This implies that groundwater quality is controlled not only by surface infiltration but also by the chemical interaction of water with aquifers materials. APC 


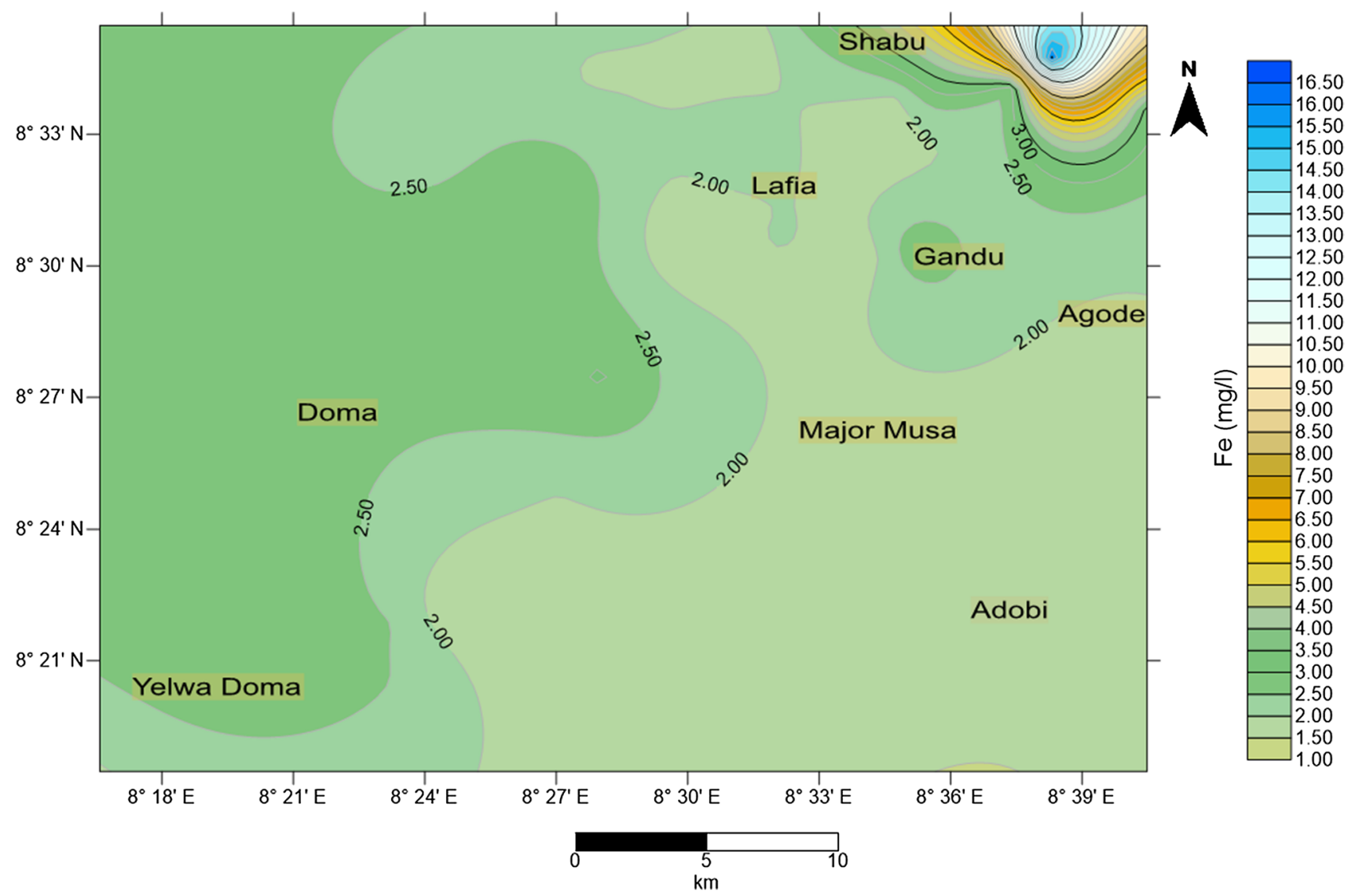

Fig. 8 Map showing the distribution of $\mathrm{Fe}^{2+}$

Table 5 WQI ratings and percentage composition

\begin{tabular}{lllll}
\hline S/no. & WQI rating & WQI range & $\%$ & $\begin{array}{l}\text { Groundwater } \\
\text { sample }\end{array}$ \\
\hline 1 & Excellent & $21.41-42.57$ & 13.33 & $9,16,17,30$ \\
2 & Good waters & $52.65-100.42$ & 30 & $2,3,4,7,12,18$, \\
& & & 19,29 \\
3 & Poor waters & $112.45-199.66$ & 40 & $1,5,8,10,11,14$, \\
& & & \multicolumn{2}{c}{$15,20,22,24}$, \\
& & & 13.33 & $13,21,23,25$ \\
4 & Very poor water & $249.52-264.44$ & 13.32 \\
5 & Unsuitable water & 456.546 & 3.33 & 6 \\
\hline
\end{tabular}

can therefore be said to be a measure of susceptibility of the aquifer to surface infiltration but not a measure of quality of the groundwater.

\section{Conclusion}

1. The study area is characterized predominantly by four geo-electric layers, namely topsoil/laterite, sandy clay, clayey sands, sandstones and shales, with the highly weathered sandstones as the aquiferous zones. Most locations with good APC do not translate into locations with good water for drinking purpose. Therefore, it is worthy of note that APC is not a measure of groundwater quality.

2. The northern, eastern and south-eastern regions have very good to good APC, constituting 4\% and 36\%, respectively. Moderate APC covers most of the central and north-eastern regions, which constitute $30 \%$, while the south-western and part of central region are dominated by poor-to-weak APC constituting $30 \%$.

3. Steel pipes and underground metal tanks can be buried in all locations except in Akurba, Bukan Fada, Akunza Jarmai, Doma new market, Madagba, Mararaba Akunza, Federal University Lafia and Kilema. These locations are moderately to slightly corrosive and therefore have the potential to corrode, deteriorate, break or cause leakage of buried steel pipes and underground iron tanks. Most locations with good APC do not translate into locations with good water for drinking purpose. Therefore, it is worthy of note that APC is not a measure of groundwater quality. 
Fig. 9 Piper trilinear diagram

Piper Diagram

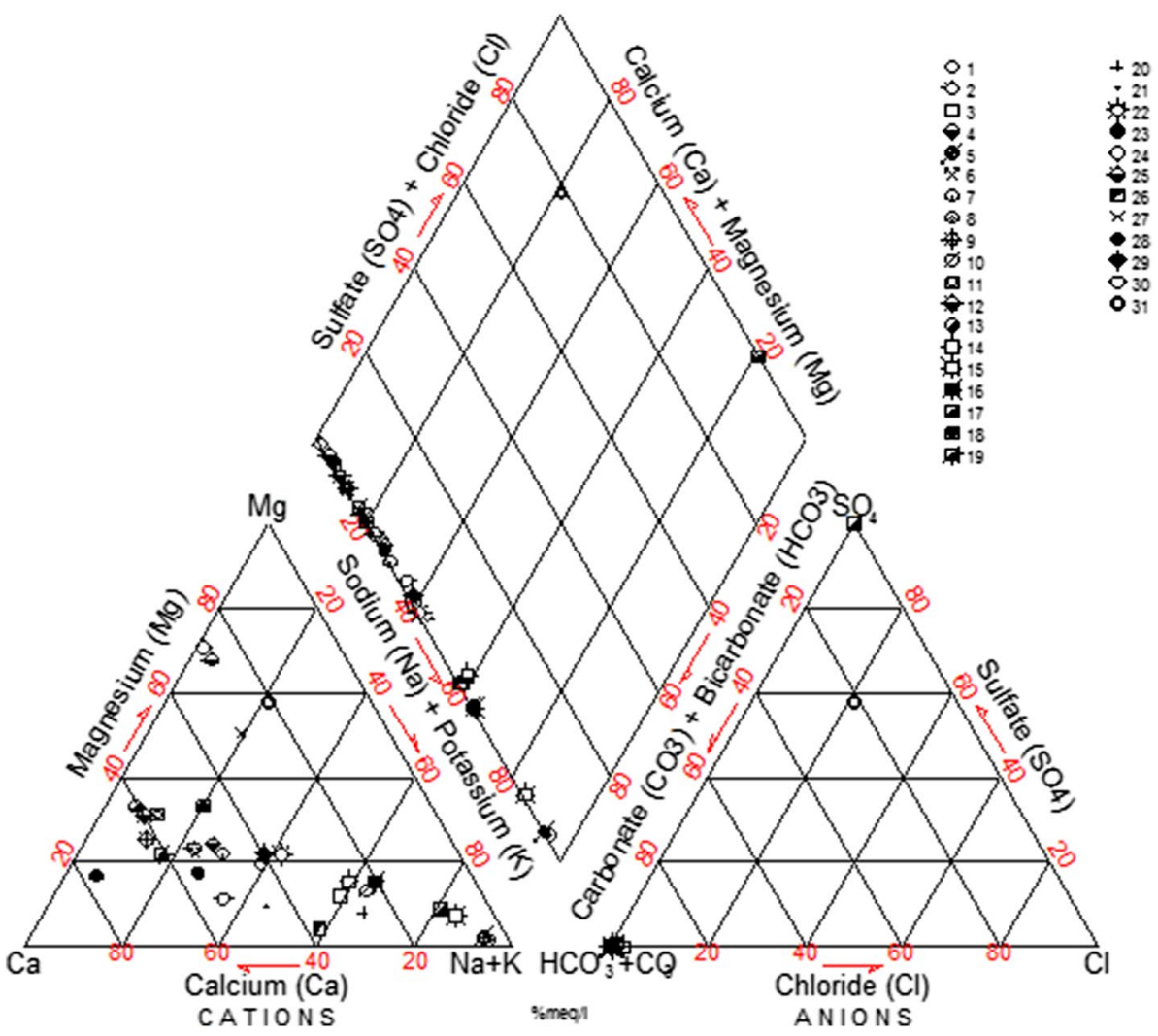

4. Concrete rings can be constructed and connected as pipes, or concrete underground reservoirs can be constructed for fluids storage in the moderately to slightly corrosive areas.

5. Five distinct water types were defined, namely excellent waters, good waters, poor waters, very poor waters and waters unsuitable for drinking purposes based on WQI.

Acknowledgements The authors are grateful to Mr. Idris Ibrahim Giza for his invaluable contributions at various stages of the research. The staff of Lifewaters and Associates Limited are also acknowledged for their assistance with data collection.

Open Access This article is distributed under the terms of the Creative Commons Attribution 4.0 International License (http://creativeco mmons.org/licenses/by/4.0/), which permits unrestricted use, distribution, and reproduction in any medium, provided you give appropriate credit to the original author(s) and the source, provide a link to the Creative Commons license, and indicate if changes were made.

\section{References}

Abiola O, Enikanselu PA, Oladapo MI (2009) Groundwater potential and aquifer protective capacity of overburden units in Ado-Ekiti, southwestern Nigeria. Int J Phys Sci 4(3):120-132

Adeniji AE, Omonona OV, Obiora DN, Chukudebelu JU (2014) Evaluation of soil corrosivity and aquifer protective capacity using geoelectrical investigation in Bwari basement area; Abuja. J Earth Syst Sci 123:491-502

Agunloye O (1984) Soil aggressivity along steel pipeline route at Ajaokuta southwestern Nigeria. J Min Geol 21:97-101

Akana TS, George GC, Oki OA (2016) Vulnerability assessment in some towns of Yenagoa, South-South Nigeria. Sci Technol 6:1523. https://doi.org/10.5923/j.scit.20160601.03

Akintorinwa OJ, Abiola O (2011) Sub-soil evaluation for pre-foundation study using geophysical and geotechnical approach. J Emerg Trends Eng Appl Sci 2(5):858-863

Atakpo EA, Ayolabi EA (2009) Evaluation of aquifer vulnerability and the protective capacity in some oil producing communities of western Niger Delta. Environmentalist 29:310-317. https:// doi.org/10.1007/s10669-008-9191-3

Baeckmann WV, Schwenk W (1975) Handbook of cathodic protection: the theory and practice of electrochemical corrosion protection technique. Surrey Protucullin Press

Batabyal AK, Chakraborty S (2015) Hydrogeochemistry and water quality index in the assessment of groundwater quality for drinking uses. Water Environ Res 87(7):607-617 
Burschil T, Scheer W, Kirsch R, Wiederhold H (2012) Compiling geophysical and geological information into a 3-D model of the glacially-affected island of Föhr. Hydrol Earth Syst Sci 16:3485-3498

Carrol R (1962) The influence of lung scars on primary lung cancer. J Path Bact 83:293-297

Dahlin T (2001) The development of DC resistivity imaging techniques. Comput Geosci 27:1019-1029

Egbueri JC (2018) Assessment of the quality of groundwaters proximal to dumpsites in Awka and Nnewi metropolises: a comparative approach. Int J Energy Water Res. https://doi.org/10.1007/ s42108-018-0004-1

Ehirim CN, Nwankwo CN (2010) Evaluation of aquifer characteristics and groundwater quality using geoelectric method in Choba, Port Harcourt. Arch Appl Sci Res 2:396-403

Faneca Sanchez M, Gunnink JL, Van Baaren ES, Oude Essink GHP et al (2013) Sequential and joint hydrogeophysical inversion using a fieldscale groundwater model with ERT and TDEM data. Hydrol Earth Syst Sci 17:4043-4060

Gebrehiwot AB, Tadesse N, Jigar E (2011) Application of water quality index to assess suitability of groundwater quality for drinking purposes in Hantebet watershed, Tigray, Northern Ethiopia. ISABB J Food Agric Sci 1(1):22-30

Henriet JP (1976) Direct application of the Dar Zarrouk parameters in groundwater surveys. Geophys Prospect 24:344-353

Herckenrath D, Fiandaca G, Auken E, Bauer-Gottwein P (2013) Sequential and joint hydrogeophysical inversion using a fieldscale groundwater model with ERT and TDEM data. Hydrol Earth Syst Sci 17(10):4043-4060. https://doi.org/10.5194/ hess-17-4043-2013

Ibuot JC, Akpabio GT, George NJ (2013) A survey of repository of groundwater potential and distribution using geoelectrical resistivity method in Itu L.G.A., Akwa Ibom State, Southern Nigeria. Cent Eur J Geosci 5(4):538-547

Makeig KS (1982) National buffers for sludge leachate stabilization of groundwater. Geophysics 20:420-429

Mgbenu CN, Egbueri JC (2019) The hydrogeochemical signatures, quality indices and health risk assessment of water resources in Umunya district, southeast Nigeria. Appl Water Sci 9:1-19

Mosuro GO, Omosanya KO, Bayewu OO, Oloruntola MO et al (2017) Assessment of groundwater vulnerability to leachate infiltration using electrical resistivity method. Appl Water Sci 7:2195-2207. https://doi.org/10.1007/s13201-016-0393-4
Obiora DN, Ajala AE, Ibuot JC (2015) Evaluation of aquifer protective capacity of overburden unit and soil corrosivity in Makurdi, Benue state, Nigeria, using electrical resistivity method. J Earth Syst Sci 124:125-135

Offodile ME (2014) Groundwater study and development in Nigeria. Mecon Geology, Jos

Oladapo MI, Mohammed MZ, Adeoye OO, Adetola OO (2004) Geoelectric investigation of the Ondo-State Housing Corporation Estate Ijapo Akure southwestern Nigeria. J Min Geol 40:41-48

Piper AM (1944) A graphic procedure in the geochemical interpretation of water analysis. Trans Am Geophys Union 25:914-923

Ramakrishnaiah CR, Sadashvaiah C, Ranganna G (2009) Assessment of Water Quality Index for the Groundwater in Tumkur Taluk, Karnataka State, India. Eur J Chem 6:523-530

Reza R, Singh G (2010) Assessment of ground water quality status by using water quality index method in Orissa, India. World Appl Sci J 9:1392-1397

Tiwari AK, Singh AK, Singh AK, Singh MP (2017) Hydrogeochemical analysis and evaluation of surface water quality of Pratapgarh district, Uttar Pradesh, India. Appl Water Sci 7:1609-1623

Todd DK, Mays LW (2005) Groundwater hydrology. Wiley, New York

Umar ND, Idris IG, Abdullahi AI (2018) Hydrogeophysical investigation of the aquifers of brine field of Awe and environs, Central Benue trough, Nigeria. Int J Sci Eng Res 9:1852-1868

Vereecken H, Hubbard S, Binley A, Ferre T (2004) Hydrogeophysics: an introduction from the guest editors. Vadose Zone $\mathrm{J}$ 3:1060-1062

WHO (2011) Guidelines for drinking water quality. World Health Organization, Geneva

WHO (2017) Guidelines for drinking water quality, 3rd edn. World Health Organization, Geneva

Zohdy AAR, Eaton GP, Mabey DR (1974) Application of surface geophysics to groundwater investigations. United State Geophysical Survey, Washington

Publisher's Note Springer Nature remains neutral with regard to jurisdictional claims in published maps and institutional affiliations. 